\title{
Innovating at pace during crisis-military lessons for the COVID environment
}

Army Medical Services, British Army, Andover, UK

\section{Correspondence to} Brigadier Tim Hodgetts, Head Army Medical Services, Army Headquarters, Andover SP11 8HT, UK;

timothy.hodgett5793@mod. gov.uk

Received 20 April 2020 Accepted 12 May 2020 Published Online First 2 June 2020

Check for updates

(C) Author(s) (or their employer(s)) 2020. No commercial re-use. See rights and permissions. Published by BMJ.

To cite: Hodgetts BT. BMJ Leader 2020:4:105-108.

\author{
Brigadier Tim Hodgetts
}

\section{ABSTRACT}

The challenges of innovating at pace in recent conflicts has encouraged military medical lessons to be codified into an integrated model of innovation, with generic application for the wider healthcare sector and the COVID environment specifically. This 'Toolset for innovation and change' emphasises the need to first understand and frame the problem using external (STEEPLE) and internal (TEPID COIL) factor analysis. The conditions that support exemplar innovation adoption by an organisation are described (ADOPTER-Agile, Decisive, Outcome focused, Politically aware, Tolerant of Risk, Empowered and Rewarded) as are the conditions that are necessary for successful innovation translation to another organisation (TRANSL8-Transformational leadership, Relevance, Adaptability/Acceptability, Networks, Simplicity, Life enhancing change, 8-steps of complex change). The obstructions to innovation, or 'innovation constipation', are highlighted and remembered as B-OWELS. The toolset was first developed by the author in 2015 from sustained experience of innovation at pace and has been successfully applied to messy problems requiring complex change in both the military and civilian healthcare sectors.

\section{INTRODUCTION}

We are currently engaged in a global war against the corona virus. This is not a war of choice, as we may have fought in recent years in Iraq and Afghanistan, but a war of national survival. It is not being fought in a far-off country, remote from the public's mind, but rather it is a war we are fighting at home and affecting every citizen directly, while drawing on the collective resources of the international community to innovate at pace.

After over a decade of driving sustained innovation in combat casualty care in the Kosovo, Iraq and Afghanistan campaigns from 1999, I analysed why we had achieved extraordinary and unexpected clinical outcomes ${ }^{1}$ and codified this into a 'Toolset for innovation and change' in 2015. This is a generic framework I have serially applied to messy problems within the military environment, to teaching National Health Service (NHS) executives, to supporting a Royal College in planning a way out of a manning crisis and to proctoring a failing NHS Trust out of Special Measures. Here I offer the toolset for application to guide thinking for clinicians and clinical managers wrestling with the complexity and uncertainty of the COVID-19 crisis.

\section{THE IMPERATIVE FOR INNOVATION}

When I first read John Kotter's sentinel book on Leading Change in 2002, I wished I had read it earlier. I had just spent 18 months designing a systematic approach to reducing avoidable in-hospital cardiac arrest, battling to implement across a whole hospital, publishing the evidence base $\mathrm{e}^{34}$ and propagating training materials to every acute Trust with the support of industry. It would have been so much easier if I had learnt from Kotter's eight-step process. But I have also learnt over the years that Kotter was wrong. There are not eight steps. There are nine.

The missing step is the first and it is critical: understand and frame the problem. Antonio Giustozzi made the observation of our approach in Afghanistan ${ }^{5}$ that, '...the folly of our age could be defined as an unmatched ambition to change the world, without even bothering to study it in detail and understand it first'. To understand the imperative for innovation, it is necessary to consider the external drivers and the internal drivers. In my parallel article on 'Transferable lessons from a field hospital', ${ }^{6}$ I have described the internal drivers of a new capability through the acronym TEPID COIL. Those who have flicked through any management book will have come across the external factors as PEST (Political, Economic, Social, Technical) or PESTLE (adding Legal and Environmental). I prefer STEEPLE, because in medical innovation, there is always that extra Ethical dimension.

In the drive to continuously improve combat casualty care, there was a strong Political will to minimise the mortality and morbidity from combat injury. The Social mood was of low tolerance to images of flag-draped coffins passing through crowds of mourners in Wootton Bassett as they transited from the military airhead to Oxford for postmortem. This casualty aversion in wars of choice is well recognised. The public tolerance may be set at a higher level for wars of necessity and national survival, but the very numbers of deaths and the prediction of exponential rise have been the stimulus for innovation at scale and pace within the pandemic.

Technology is a key enabler to innovation. For combat casualty care, it was focused on stopping bleeding, the most common cause of avoidable combat injury death. Serial technology developments occurred with first step change, then incremental improvement to create one-handed tourniquets and topical haemostatic agents. An emergent approach was expressly written into the haemostatic strategy: we had the vision to know that industry would compete and offer future improved alternatives, so we did not overprocure and had the agility to change tack when the opportunity arose. Innovation also led to repurposing of existing technology: old and simple technology to 
quantify blood clotting (thromboelastography) took on a new and transformative purpose when placed in the field hospital operating theatre to help the anaesthetist in real-time tailor the blood products during a massive transfusion.

The Economic imperatives for innovation are twofold. At the business level, they bring opportunity if you can supply what is needed or invent a novel solution. At the macroeconomic level, the global economic challenge of COVID-19 is profound, with 'non-essential' workers across industry required to socially distance at home. In the UK, this has provided the necessity, capacity and corporate social responsibility for manufacturers to repurpose and collaborate to meet the national main effort.

While necessity can break down bureaucracy, there will still be Legal constraints and accountability. All operational deaths in Iraq and Afghanistan were subject to Coronial inquiry in the UK. This was principally a powerful enabler of rapid change, with military clinical and government scientific analysts attending every single postmortem to understand what more might be possible in body armour and vehicle protective systems, or in treatment. Health and Safety Executive direction to employers is to report COVID-19-related illness or death, and employers can expect to be held accountable for providing a safe working environment.

Environmental considerations are increasingly a factor in clinical innovation. Remote consultation improves convenience, it reduces travel; 3D printing ('distributed manufacturing') of a spare part increases agility while reducing shipping and material choice for manufacture or packaging has environmental consequences.

But for me, it is Ethics that presents an Achilles' heel. With the eye of the media constantly on us, it is not what we can do, but what we choose to do that creates the ethical challenge. As the Medical Director of field hospitals in Iraq and Afghanistan, I faced a daily internal conflict of who could be admitted and who would be admitted, dependent on the hospital's capacity. I called it 'good doctor theory' (teleology) versus 'good soldier theory' (deontology). A perpetual tension between keeping capacity to treat the injured soldiers (our purpose) and our desire to treat the local population is in need (our humanity). My first action when a field hospital was nominated for the Ebola crisis in 2014 was to call an ethical conference. Who will we treat and what standard of care do we set? Do we allow emerging experimental treatments? Can we bring our own sick home? Without answering these fundamental questions, you cannot sensibly plan the manpower, equipment and clinical guidelines. More importantly, you will fail to generate a unity of purpose and a committed followership.

\section{INNOVATION ADOPTION}

I first tried to adopt innovation at scale in 1997 to introduce a new bandage to the Army. At that time, our procurement process was the same for a new bandage as it was for a new tank. Not surprisingly, it was measured in years. But at the height of serial clinical innovation in 2007, during concurrent operations in Iraq and Afghanistan, that time was reduced to a matter of days. I had struggled with getting a drip into a seriously injured soldier on the back of the military rescue helicopter (let us just get the context here, the helicopter is flying fast, 50 feet above the ground following the ground contours; I am on my knees next to a patient, who is unrestrained on a canvas stretcher; there is no light; and all the doors are open, manned by gunners-it is a rollercoaster without a seatbelt or popcorn) and 'reflected' we needed the new adult intraosseous drill. The clinical imperative was inarguable. But why were we now able to take an external innovation so quickly? Because we had become an exemplar innovation ADOPTER-Agile, Decisive, Outcome focused, Politically aware, Tolerant of risk, Empowered and Rewarded.

Agility is a function of both size and mindset. The Defence Medical Services is tiny compared with the NHS, so it can change direction very quickly if it chooses. Yet the NHS has demonstrated remarkable agility in the COVID-19 crisis to build and equip temporary hospitals to high specification in just 10 days. It is the mindset that is key.

Decisiveness, in my opinion, is the most important leadership characteristic in crisis. In 1989, I had to make a decision whether to evacuate after a telephoned bomb threat to a military hospital; in 1991, I was in another military hospital when it was blown up by the IRA and I was the Medical Commander. Evacuate or do not evacuate? The correct answer is 'Either'. The incorrect answer is 'I don't know'.

Process has its place, but my focus is on Outcome. It is more important in a crisis to get the right resource and do the right thing than it is to fixate on the process by which it is achieved. This will make the process-oriented very uncomfortable.

'War is a continuation of politics by other means' was an observation by Clausewitz ${ }^{7}$ in 1832 . Awareness of the Political dimension to a crisis and understanding this will enable innovation to be framed as addressing political concerns.

The military has two prevailing cultures-the 'operational' culture that is characterised by Tolerance of risk, and the 'firm base' culture that is bureaucratic, heavily regulated and risk averse. No Army ever won a battle, let alone a war, without taking risk. Equally, innovation at pace demands risk and the willingness to act ahead of the competition with 'good enough' information. Academic purism and the search for perfection in a crisis can be the enemy of pragmatic action. As the saying goes, ' $80 \%$ on time is better than $100 \%$ too late'.

Empowerment is provided through 'mission command'. ${ }^{8}$ As soldiers often work remotely from their commander, they have to understand his or her intent through formal orders. They are then empowered to act on these, without repeatedly asking for permission, enabling exploitation of time-limited opportunities that can be the difference between winning and losing.

Look around you and ask how many of your colleagues have been Rewarded for their clinical excellence and innovation? Do you know how to nominate someone for an award? Have you tried? Soldiers do extraordinary things satisfied in the reward of praise, a promotion in rank or simply the ribbon to a metal disc or cross.

\section{INNOVATION TRANSLATION}

If innovation adoption is taking others' great ideas and internalising them within the organisation, innovation translation is taking your own great ideas (concepts, practices, processes and equipment) and spreading them externally. In large organisations, such as the NHS, this can include other parts of the organisation, an obvious example in the COVID environment being how one temporary Nightingale hospital might learn from another as they became operational sequentially. Translation also occurs between industry sectors (NHS, Defence Medical Services, third sector charities and the private sector) and internationally, with common and established sharing practices in NATO and the ' 5 Eyes' community (UK, USA, Canada, Australia and New Zealand).

The conditions for successful innovation translation can be codified as TRANSL8-Transformational leadership, Relevance, 
Adaptability/Acceptability, Networks, Simplicity, Life-enhancing effect and Kotter's eight-step model of change. Remembering, of course, that Kotter was wrong and there are nine steps!

Innovation will not succeed, certainly not at pace, without a champion. A transformational leader. In Afghanistan during the peak of combat casualty tempo in 2009, we introduced the process of 'Right turn resuscitation'. ' Critically injured were taken direct from the ambulance to the operating theatre where the whole team had assembled, scrubbed, opened instrument packs and spiked universal donor blood and plasma: this profoundly reduced time to life-saving surgery when it was the determinant of successful outcome. In process terms, as the patient was pushed into the emergency department, it was turn left into Resuscitation Bay One or turn right into Operating Theatre One. A military consultant and registrar in emergency medicine then took leadership to translate this to their host NHS Trust in St Mary's Paddington.

I have talked of the difficulty of in-flight resuscitation on the back of a military helicopter, my worst experience being 11 casualties filling every inch of floorspace with children in the arms and across the knees of the startled Quick Reaction Force. We learnt a lot. I learnt a lot. But not all those lessons are relevant to a civilian air ambulance, which for one thing is not machinegunned and mortared when it lands in a field, necessitating an average of just $2 \mathrm{~min}$ on the ground to load casualties before take-off, with all assessment and treatment in the air.

The military like every piece of equipment to be green, black or camouflaged. We hate dayglo yellow or orange. We do not want to be seen. Yet a black tourniquet was a problem. 'It won't be seen at the hospital', said the civilian paramedic. Then, industry made it dayglo orange. This adaptation made it acceptable.

Change can be ordered from the top down, but for change to stick, it needs the buy-in of the clinical community. Most meaningful clinical change in combat casualty care came from the middle layer of clinical subject matter experts, spreading up (to inform policy) and down (to inform practice). The experience of rapid serial innovation in the field was brought home by the network of regular and reservist personnel whose peacetime role is embedded in the NHS. Some are grouped in key partnership Trusts, but many are widely dispersed across health throughout the devolved administrations. This created an ink blot effect to transfer innovation widely, where those blots joined to create a national level of influence in the evolution of the Major Trauma Centre network.

The simpler an innovation, the easier it is to translate. A simple solution to keeping blood and thawed plasma at four degrees and carry it all day on the rescue helicopter was a polystyrene box. It was trialled and it worked. So long as the doctor was not tempted to open it and check the blood was in it, at which point it had to be used. This idea was rapidly translated into the charity air ambulance community.

If the impact of the innovation is not life enhancing for the patient, stop and ask yourself why bother? There is plenty of innovation to be getting on with that will affect patient outcome, experience or safety. Granted, staff health and well-being and optimising performance are a parallel requirement as our people are our currency to deliver these life-enhancing effects.

Finally, to translate innovation, I do recommend a model for complex change and Kotter's eight steps are as good as any. 'Creating a crisis' is an art, knowing the organisational buttons to press that will generate action, but having the solution rather than just a problem is fundamental. 'Generating and communicating a vision' that is simple, clear and repeated at every opportunity will create the tipping point of awareness and support.
'Building a guiding coalition' needs to be based on competence not just representation, or you will be doing all the work yourself. 'Overcoming obstacles' may be money, but more likely people and perhaps people in charge of money. The rest is implementation, evaluation and bedding into corporate culture.

\section{INNOVATION CONSTIPATION}

Obstruction to innovation is the norm. Expect it, or better anticipate it and try to head it off. It is the 'overcoming obstacles' step of Kotter's model. Most people do not like change. If you throw a loaf of bread, the birds will scatter; but they will happily feed on crumbs. Not all innovation and change needs to be disruptive. The mnemonic here is B-OWELS. This stands for Bullying, followed by the vowels-Apathy (a lack of motivation), Exploitation (a lack of reward), Impotence (a lack of empowerment), Opposition (a resistance to change) and Unappreciation (a lack of recognition). Yes it is abstract, but I am not clever enough to make the acronym match!

Bullying is a fire blanket to innovation and a factor that has contributed to clinical leadership failure with catastrophic consequences. ${ }^{10}$ People will not take the risk to innovate in a prevailing culture of bullying: it is counterintuitive to self-preservation. Effort and reward are inextricably linked: that is basic motivation or 'expectancy' theory. ${ }^{11}$ Intrinsic reward (from appreciation) is at least as important as extrinsic reward (from payment). Opposition to change, as I have said, is invariably from people. When at work, it is become more important to do it the right way than to do the right thing, then you are working in a Process Zoo where the behaviour of the 'animals' and the 'keepers' is quite predictable. Check them out. ${ }^{12}$

\section{FINAL THOUGHTS}

This may all have sounded logical, which it is, and easy, which it most definitely is not. Where I have identified decisiveness as the most valued leadership characteristic in crisis, ${ }^{6}$ perhaps the most valuable in innovation is determination. My career is littered with good ideas that have not transpired into products, but with enough success to give me confidence that determination is essential, particularly when you know it is the right thing to do. Having vision is a blessing, but a curse when others may not share it until it comes true. I had the vision to establish the system of major trauma governance for the military in 1997 and manage it for 13 years, first demonstrating effectiveness at local level, ${ }^{13}$ then on operations in Kosovo. ${ }^{14}$ Yet the first few years were possible only through good will and collective clinical insight that it was the right thing to do, until it became clear it was central to organisational success during the Iraq and Afghanistan conflicts. ${ }^{15}$ It was then fully resourced. Determination saw this through, but I did receive both intrinsic and extrinsic reward!

If you have read to the end, you are clearly stimulated by innovation. My challenge in crisis is for you to dare to think differently. Dare to take reasoned risk. Dare to innovate. After all, 'Only dead fish follow the flow .

Contributors $\mathrm{TH}$ is the sole author of this work and the novel innovation concepts within it.

Funding The authors have not declared a specific grant for this research from any funding agency in the public, commercial or not-for-profit sectors.

Competing interests None declared.

Patient consent for publication Not required.

Provenance and peer review Not commissioned; internally peer reviewed.

This article is made freely available for use in accordance with BMJ's website terms and conditions for the duration of the covid-19 pandemic or until otherwise 
determined by BMJ. You may use, download and print the article for any lawful, non-commercial purpose (including text and data mining) provided that all copyright notices and trade marks are retained.

\section{ORCID iD}

Brigadier Tim Hodgetts http://orcid.org/0000-0002-8542-1423

\section{REFERENCES}

1 Hodgetts TJ. A revolutionary approach to improve combat casualty care. London: City University of London, 2012.

2 Kotter JP. Leading change. 2nd edn. Harvard: Harvard Business Review Press, 2012

3 Hodgetts TJ, Kenward G, Vlackonikolis I, et al. Incidence, location and reasons for avoidable in-hospital cardiac arrest in a district general Hospital. Resuscitation 2002;54:115-23.

4 Hodgetts TJ, Kenward G, Vlachonikolis IG, et al. The identification of risk factors for cardiac arrest and formulation of activation criteria to alert a medical emergency team. Resuscitation 2002;54:125-31.

5 Giustozzi A. Empires of mud: wars and Warlords in Afghanistan. Chichester: Columbia University Press, 2009.

6 Hodgetts TJ. Transferable lessons for clinical leadership of a field Hospital. BMJ 2020.
7 Clausewitz Cvon. On war. Oxford: Oxford World's Classics, 2008.

8 Pearce AP, Naumann DA, O'Reilly D. Mission command: applying principles of military leadership to the SARS-Cov-2 (covid-19) crisis. BMJ Mil Health (Published Online First: 16 Apr 2020).

9 Hettiaratchy S, Tai N, Mahoney P, et al. Uk's NHS trauma systems: lessons from military experience. Lancet 2010;376:149-51.

10 Francis R. Report of the mid Staffordshire NHS Foundation trust public inquiry (HC 947). London: The Stationery Office, 2013.

11 Simone Sde. Expectancy value theory: Motivating healthcare workers. American International Journal of Contemporary Research 2015;5:19-23.

12 Hodgetts TJ, Gibson C, Mahoney P. How to manage a sloth (and other animals in the process z00). Chartered management Institute, 2017. Available: https://www. managers.org.uk/insights/news/2017/february/how-to-manage-a-sloth-and-otheranimals-in-the-process-zoo [Accessed 19 Apr 2020].

13 Hodgetts T, Turner L, Payne S. Major trauma project: 3 year report, 1997-2000. London: Defence Logistics Organisation, 2001.

14 Hodgetts TJ, Kenward G, Masud S. Lessons from the first operational deployment of emergency medicine. J R Army Med Corps 2000;146:134-42.

15 Smith J, Hodgetts T, Mahoney P, et al. Trauma governance in the UK defence medical services. J R Army Med Corps 2007;153:239-42. 